\title{
Bursa Müzesi’ndeki İki Erkek Portresinin Yeniden Değerlendirilmesi
}

\author{
Araş. Gör. Yaşar Arlı ${ }^{*}$
}

Gelis tarihi: 12.11 .2019

Kabul tarihi: 06.12.2019

\section{Atıf bilgisi:}

IBAD Sosyal Bilimler Dergisi

Sayı: 6 Sayfa: $46-53$

Yıl: 2020 Dönem: Kı̧̣

This article was checked by intihal.net. Similarity Index 9\%.

Bu makalede araştırma ve yayın etiğine uyulmuştur.

1 Akdeniz Üniversitesi, Türkiye, yasararli@akdeniz.edu.tr

ORCID ID 0000-0001-7799-6764
ÖZ

Uluslararası portre araştırmacılığı alanında karşımıza çıkan en önemli husus bir portrenin resmi mi yoksa özel mi olduğu sorusudur. Bu soru aynı zamanda ele alınan portrenin hangi imparator veya imparatoriçeye ait olduğunu ya da hangi imparator veya imparatoriçeden esinlenerek ortaya konduğu sorularının cevaplarını da bizlere sunmaktadır. Bu önemli husus, ele aldığımız eserin tanım ve tarihlendirilmesinde de bizlere yol gösteren önemli bir faktördür. Uluslararası portre araştırmacılığı kriterlerine sadık kalarak ele aldığım bu yazımda, son olarak 2013 yılında R. Özgan tarafindan yayımlanan Bursa ve çevresinden ele geçen erkek başları, yeniden yorumlanmış ve her iki eser için haklı gerekçeler gösterilerek yeni bir öneri getirilmeye çalışılmıştır.

Anahtar Kelimeler: Erkek, Baş, Portre.

\footnotetext{
* Sorumlu yazar
} 


\section{Reassessment of Two Male Portraits in Bursa Museum}

\section{Res. Assist. Yaşar Arlı ${ }^{*}$}

First received: 12.11 .2019

Accepted: 06.12.2019

\section{Citation:}

IBAD Journal of Social Sciences

Issue: 6

Pages: $46-53$

Year: 2020

Session: Winter

This article was checked by intihal.net. Similarity Index 9\%.

1 Akdeniz University, Turkey, yasararli@akdeniz.edu.tr

ORCID ID 0000-0001-7799-6764

* Corresponding Author

\begin{abstract}
The most important point in the field of international portrait research is the question of whether a portrait is official or private. This question also provides us to answers the questions that to which emperor or empress the portrait discussed belonged or from which emperor or empress the portrait was done by inspiring. this important issue is an important factor guiding us for the identification and dating of the piece. In my paper based on international portrait research criteria, male heads which were obtained from Bursa and its surrounding and recently published by R. Ozgan in 2013 have been reinterpreted and a new suggestion has been tried to be brought by giving justified reasons for both pieces.
\end{abstract}

Keywords: Male, Head, Portrait. 


\section{INTRODUCTION}

It is not known exactly where and how the male heads of which finding places are indicated as Prusa (ad Olympum) and Bursa, with the modern name for the other one in the inventory records were brought to Bursa Archeology Museum. The first of these two pieces which are only known to be obtained from Bursa and its environs has been examined by many researchers until today. Prusa head which was first written by J. İnan and E. A. Rosenbaum in 1979 was evaluated by S. Erkoç in 2012 and by R. Özgan in 2013. In the same study, R. Özgan introduced Bursa head to the scientific world and dated both pieces to the Flavian period.

\section{Male Head (Plate I)}

Bursa Archeology Museum

(Inv. No. 2096).

Prusa ad Olympum.

H. H. 27 cm, H. W. 19 cm.

Fine-grained white marble.

Iulio- Claudian Period

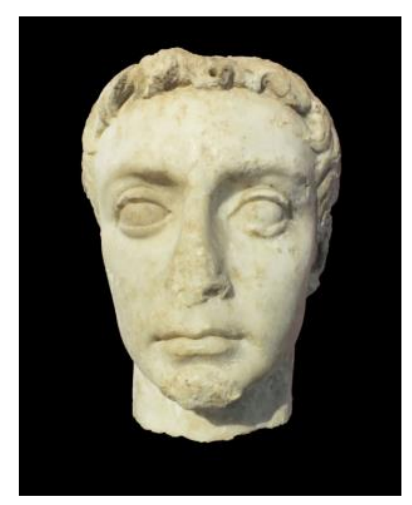

Sources: İnan-Rosenbaum 1979, 141, 142 Plate 75 Figure 1, 2, 3, 4; Erkoç 2012, 146, 147 Plate 112; Özgan 2013, 120, 121.

The head is broken from the beginning of the neck. There can be seen abrasions and bruises on the face. The end of the nose is broken. There are seen abrasions and missing parts on the chin. There is a tear-off at the top of the head.

Considering the characteristic features of the head, the piece must have belonged to a young man. The head is turned slightly to the right. The head turned to the right looks far away. Short hair tufts on the forehead are quite bulky and voluminous. On the right side of the forehead is the hair forelock which is described as pliers mouth. The short hair tufts on the forehead are combed towards the right by being separated from left temporal. The end part of hair tumpts combed towards the forehead on the ear is wavy and bulky. The hair tufts on the left ear are described in more detail than the right. The hair tufts in the rear of the forehead are longer than the hair on the forehead. The hair tufts described at the top and rear part of the head are quite moving and lively. Pointed whiskers on the left part of the face created by being stretched the hair tufts in the front of the ear reach towards the cheek. The forehead bordered by the hair on the temporal area is flat and narrow. The lower part of the flat and narrow forehead is slightly puffed. The eyebrows are in the form of a bow and explicit. The eyes stretching to eye dispensers are narrow. The pupil and iris are not processed. The upper eyelid is thicker than the lower one. The nasal root is sunken, the nose is slightly beaked. The ears processed in accordance with the facial anatomy are close to the real. The cheekbones are explicit, the cheeks are plump. The mouth is closed and big. The lips are in contact with each other and the upper lip is thinner than the lower one. The chin is fat and cambered outward. The non-oval face is pointed towards the chin. The well-polished face is smooth. There are dowel holes on the forehead which belong to a crown in my opinion.

There are different views and suggestions about the male head examined by many researchers. Prusa ad Olympum head which was dated to Iulio- Claudian period by J. İnan ve E. A. Rosenbaum in 1979 (İnan and Rosenbaum, 1979, p. 142) was interpreted also as a special portrait dated to Flavian period by R. Özgan in 2013 (Özgan, 2013, p. 121). Also, S. Erkoç (Erkoç, 2012, p. 147) shared the same opinion with J. İnan and E. A. Rosenbaum in her doctoral thesis study completed in 2012.

R. Özgan suggested the Flavian period by stating about the male head that it reflected the real physiognomic features of the person of whom portrait was made (Özgan, 2013, p. 120, 121). This view has been supported by being compared flat and narrow forehead of the person of whom portrait was made with portraits of Domitianus (Fittschen and Zanker, 1985, plate 34, 35). As R. Ozgan stated, when 
we compare the Prusa ad Olympum piece with the portraits of the Flavian Dynasty, it is seen that its physiognomic features are not similar. For example, signs of aging such as rare hair and sagging skin are at the forefront in portraits of Vespasianus (Fittschen and Zanker, 1985, plate 27, 28). Descriptive features such as broad face and forehead and curly and voluminous hair are remarkable in portraits of Titus (Wegner, 1966, plate 10, 11). In portraits of Domitianus (Wegner, 1966, plate 26, 27), the conjoined hair to the head, the forehead nearly four-cornered and thin and long neck are among characteristic features of this period. Therefore, unlike the evaluations of R. Ozgan, the processing of the hair in the portrait of Prusa ad Olympum is quite different from the portrait style of the Flavian period. When we focus on the hairstyle in male head, the hair combed towards the right by being separated from left temporal, fork motif on the left corner of the forehead, the hair forelock which is described as pliers mouth on the right side of the forehead and moving and lively hair processed at the top and rear part of the head indicate to Iulio- Claudian period (Boschung, 1993, plate 1, 2). When we compare Prusa ad Olympum piece with portraits of Tiberius preserved in France (Toulouse) (Rose, 1997, p. 126, plate 160.52) and Copenhagen (Mlasowsky, 2001, p. 87, figure 27) in the direction of these explanations, it is seen that the hairstyle processed is similar. The male head identified as a result of these similarities is a special portrait dated to Iulio- Claudian period as J. İnan and E. A. Rosenbaum and S. Erkoç stated.

\section{Male Head (Plate II)}

Bursa Archeology Museum

(Inv. No. 2092).

Bursa.

H. H. $34,5 \mathrm{~cm}$, H. W. $21 \mathrm{~cm}$.

Fine-grained white marble.

Iulio-Claudian Period

Source: Özgan 2013, 121, 122.

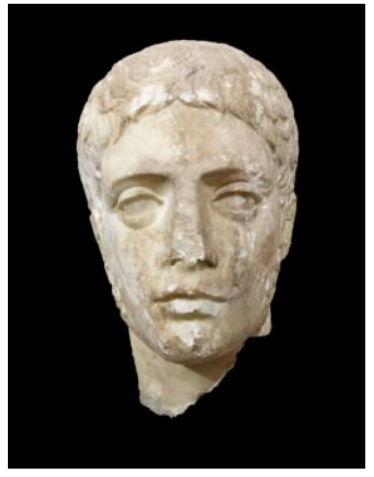

The head is broken and missing from the beginning of the neck. There are abrasions and bruises on the face. The end part of the nose is broken. There are missing and broken parts on the mouth, chin and rear part of the head.

Considering the characteristic features of the piece which was preserved badly until today, the head must have belonged to a young man. The head is slightly turned to the right. The head turned to the right looks far away. The short hair tufts combed towards the forehead bifurcate almost in the center of the forehead. Short, flat and thin hair strands are combed towards both sides from bifurcated area. The end parts of the tufts combed towards both sides are wavy and parallel to each other. The hair tufts in the form of sickle at the rear of the forehead are quite moving and lively.

The bulky and voluminous hair depicted at the top of the head is quite longer than the hair tufts in the front of the forehead. The static hair tufts on the back and neck of the head are left roughly. Craftsmanship for moving and lively hair on the right ear is more detailed than hair tufts on the left ear. The forehead bordered by short hair tufts on the front of the head is flat and narrow. The whiskers formed by hair tufts in the front of the ear and new beard hairs go down to lower line of the cheek. While the end of the whiskers on the left cheek is wavy and more voluminous, the whiskers on the right are shorter and rare. The eyebrows are thin and in the form of a bow. The big nose is slightly beaked. The eyes stretching to eye dispensers are narrow. The pupil and iris are not processed. The eyelids are in the form of almonds. The upper eyelid is thicker than the lower one. The ears are close to the real. The cheekbones are explicit, the pouches are sunken. The mouth is big and open. Fleshy lips are not in contact with each other. The chin is fat and cambered outward. The non-oval face is pointed towards the chin. The well-polished face was smooth. There are dowel holes on the forehead which belong to a crown in my opinion. Physiognomic features of the person of whom portrait was made are processed by idealizing. 
The arrangement of hair tresses on Bursa head shows a great resemblance to pieces of Polykleitos (Kreikenbom, 1990, plate 74, II 2, II 3; plate 75, II 3; plate 78, II 5) at first glance. Fleshy eyelids, slightly beaked nose and whiskers on Bursa portrait which reminds pieces of Polykleitos with hairstyle are characteristic features of the person of whom portrait was made and differentiate from pieces of Polykleitos (Zanker, 1974, plate 5.I; plate 7).

The male head introduced to the science world together with Prusa ad Olympum portrait in 2013 has been identified as a special portrait dated to Flavian period by R. Ozgan (Özgan, 2013, p. 121, 122) by considering same justifications with the previous piece. The hairstyle and idealized face on Bursa head which shows a great resemblance to previous Prusa ad Olympum portrait in terms of stylistics differentiate from portrait style of Flavian period. On the contrary to expressions by R. Ozgan, bifurcation created almost in the center of the forehead by short hair tufts combed towards the forehead, quite moving and voluminous hair tufts in the form of sickle at the rear of the forehead, hair on the face and idealized face are examples for portrait art of Claudian period (Hekler, 1912, p. 185, 186). The bifurcation created almost in the center of the forehead by short hair tufts combed towards the forehead and hairstyle created by moving and voluminous hair tufts in the form of sickle at the rear of the forehead on Bursa head are identical with portraits of Tiberius in the Vatican (L'Orange, 1967, p. 29) and Copenhagen (Poulsen, 1962, p. 83, plate 78). Another important point we observe on Bursa portrait that hairing on the face created together by hair tufts combed in the front of the ear and new beard hairs is similar with portrait of Nero in Rome (Delbrück, 1914, p. 6, plate 10; Heintze, 1961, p. 19, plate 14). The male head which we have evaluated as a result of these similarities should be dated to the IulioClaudian period ${ }^{1}$.

\section{CONCLUSION}

The male head which was dated to the Flavian period by R. Ozgan have not been supported as a result of scientific studies by myself and a new suggestion has been brought. The hair combed towards the right by being separated from left temporal, bifurcation motif on the left corner of the forehead, hairstyle in the form of hair forelock which is described as pliers mouth on the right corner of the forehead on Prusa head are quite different from hair model of portraits of Flavian Dynasty. Also on Bursa head, bifurcation created almost in the center of the forehead by short hair tufts combed towards the forehead and quite moving and voluminous hair tufts in the form of sickle at the rear of the forehead, hairing on the face and idealized face indicate to Iulio-Claudian period. Both pieces are dated to the same period as a result of these explanations and comparisons.

Bilgilendirme/Acknowledgement: The studies about "Roman Portrait Art" published by Prof. Dr. R. Ozgan are extremely valuable. These studies, which are particularly valuable in terms of language, play an important role in filling a large gap going on for a long time in the field of Classical Archaeology. Also, this study has been compiled from my doctoral study entitled "Portrait Art of Flavian and Traianus Periods in Anatolia" which is being conducted and continued under the consultancy of Prof. Dr. Havva Işı. Required expenditures for scientific researches conducted in 34 museums under my thesis title have been provided by Akdeniz University Scientific Research Coordination (SRP), Koç University Suna \& Inan Kiraç Research Center for Mediterranean Civilizations (AKMED), TUBITAK (2211-A) and Akdeniz University FMTP Units and I thank each unit.

\section{REFERENCES}

Boschung, D. (1993). Die bildnisse des augustus. Berlin: Gebr. Mann Verlag.

\footnotetext{
${ }^{1}$ As a result of the fact that the portraits obtained from Bursa and its surrounding until today are few, the scarcity of scientific excavations in which regular data flow is provided and random preparation of the inventory information about the portraits onbatined by various ways, it is quite difficult to mention about the existence of a strong workshop since Hellenistic Period in Prusa (ad Olympum). However, although it is difficult to mention about the existence of an ongoing workshop from the Hellenistic period onwards in Prusa (Bursa), strong idealized influence in plate II and hair style in n Polykleitos style are qualifications which support that Hellenistic tradition was preserved also in Roman Imperial Period. İnan, 1980, p. 144.
} 
Delbrück, A. v. R (1914). Bildnisse römischer kaiser. Berlin: Verlag Julius Bard.

Erkoç, S. (2012). Anadolu'da Iulius-Cladiuslar dönemi portre sanatı. Yayımlanmamış doktora tezi, Akdeniz Üniversitesi, Antalya.

Fittschen, K. \& Zanker, P. (1985). Katalog der römischen porträts in den capitolinischen museen und den anderen kommunalen sammlungen der stadt rom: band I-tafeln. West Germany: Philipp von Zabern, Mainz am Rhein.

Heintze, H. v. (1961). Römische porträt-plastik aus sieben jahrhunderten. Stuttgart: Hans e Günther Verlag.

Hekler, A. (1912). Greek \& roman portraits. New York: G. P. Putnam's Sons.

İnan, J. ve Rosenbaum, E. A. (1979). Römische und frühbyzantinische porträtplastik aus der türkeitafeln. Münih: Verlag.

İnan, J. (1980).“Ein männlicher porträtkopf im museum von Bursa” içinde R. A. Stucky - I. Jucker (ed.), EIKONES: Studien zum griechischen und römischen bildnis: Hans Jucker zum sechzigsten geburtstag gewidmet, p. 143-144 Plate 48. Bern: Francke Verlag.

Kreikenbom, D. (1990). Bildwerke nach polyklet: Kopienkritische untersuchungen zu den männlichen statuarischen typen nach polykletischen vorbildern -diskophoros, hermes, doryphoros, herakles, diaudumenos. Berlin: Gebr. Mann Verlag.

L'Orange, H. P. (1967). Romerske keisere: i marmor og bronse. Oslo: Dreyers Forlag.

Mlasowsky, A. (2001). Imago imperatoris: Römische kaiserbildnisse einer norddeutschen sammlung. Münich: Biering\&Brickmann.

Özgan, R. (2013). Roma portre sanatı II. İstanbul: Ege Yayınları.

Poulsen, V. (1962). Les portaits romains I: république et dynastie julienne. Copenhague: Ny Carlsbeg.

Rose, C. B. (1997). Dynastic commemoration and imperial portraiture in the Julio-Cladian period. ABD: Cambridge University.

Zanker, P. (1974). Klassizistische statuen: Studien zur veränderung des kunstgeschmacks in der römischen kaiserzeit. West Germany: Verlag Philipp von Zabern, Mainz am Rhein.

Wegner, M. (1966). Das römische herrscherbild: die flavier (vespasian.titus.domitian.nerva.lulia titi.domitilla. domitia). Berlin: Verlag Gebr. 


\section{Plate I}
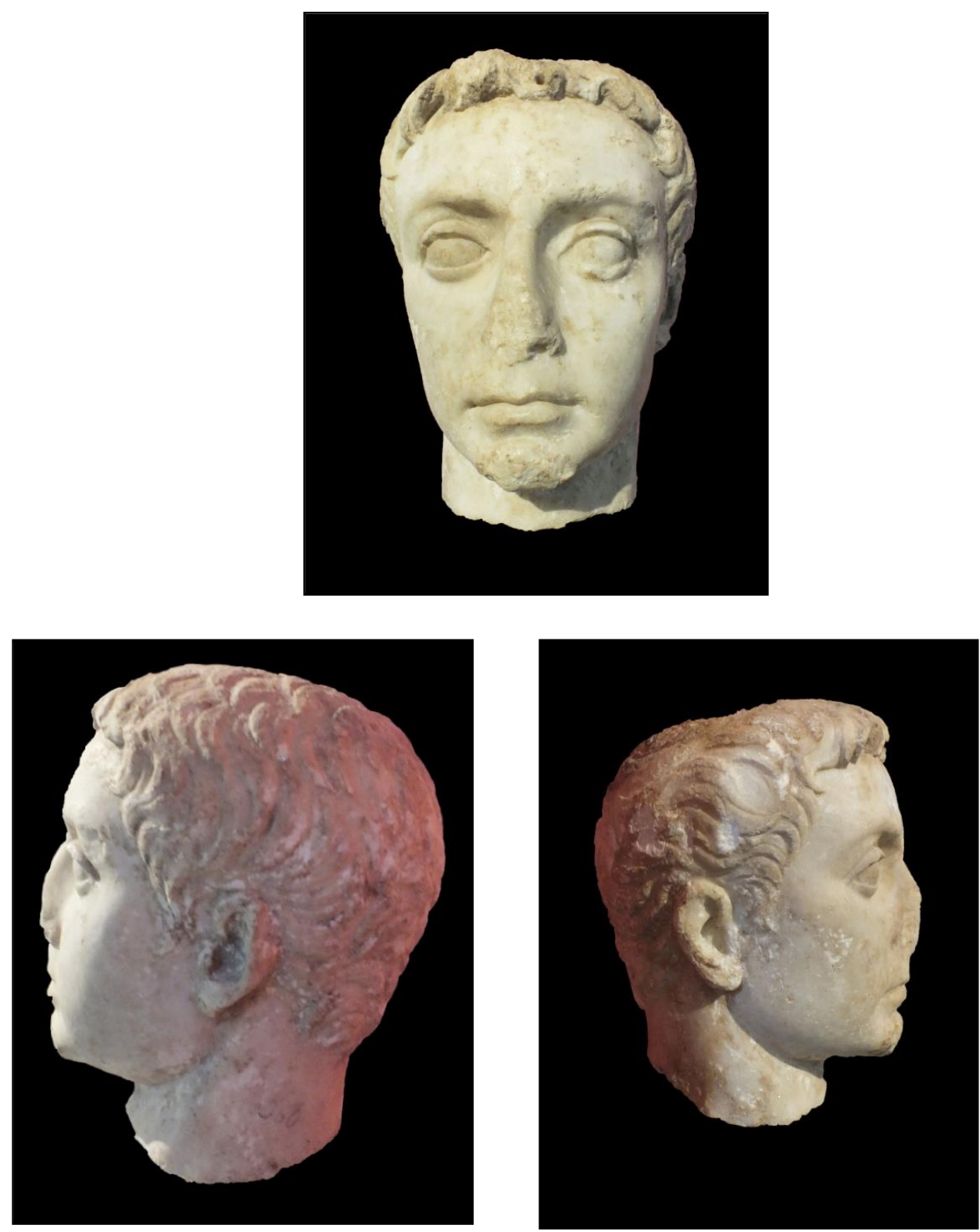

Plate I: Prusa (ad Olympum) Head. (Photo: Yaşar Arlı, 2018). 


\section{Plate II}
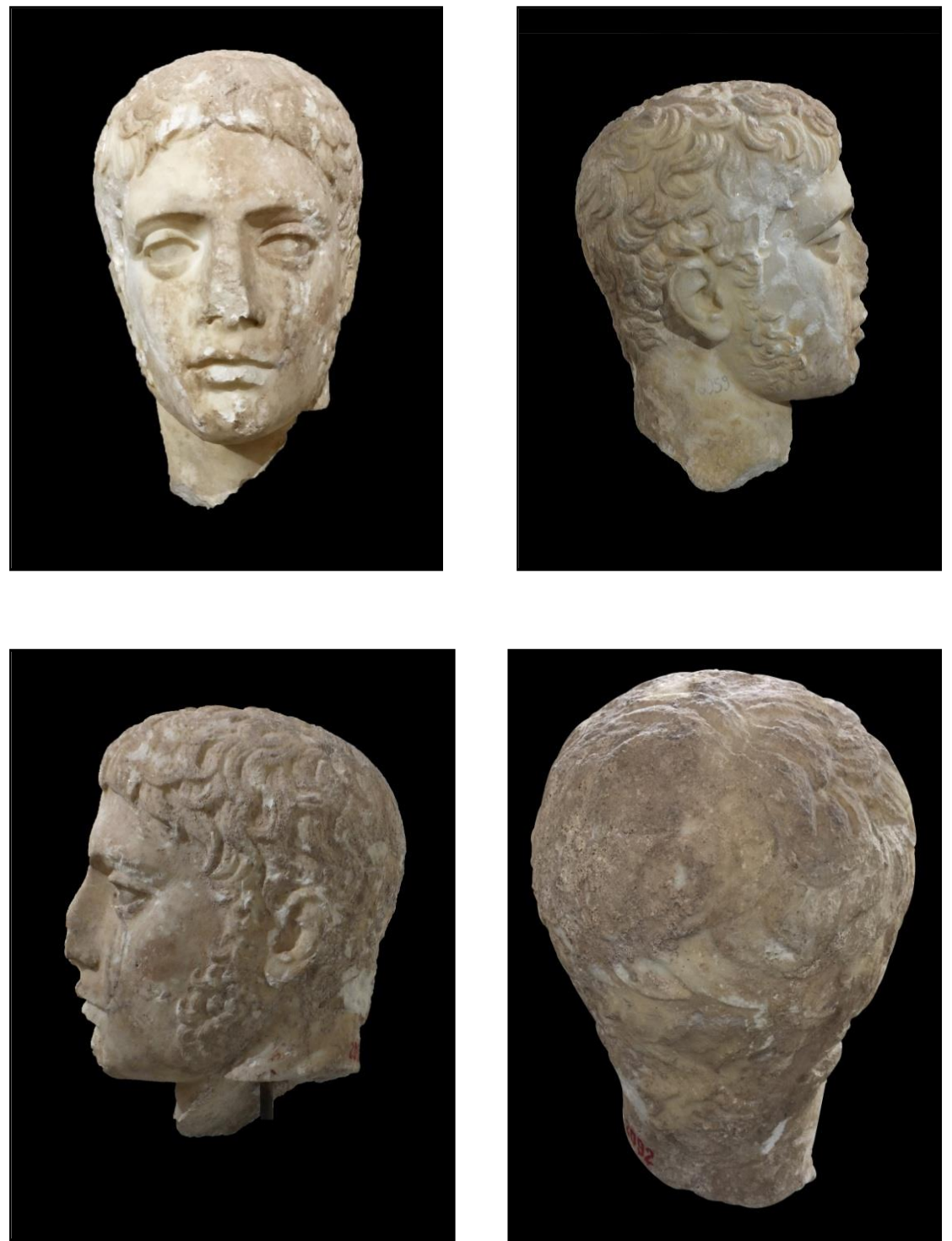

Plate II: Bursa Head. (Photo: Yaşar Arl1, 2018). 